\title{
OBESITY, PARITY, AND THE INCIDENCE OF CERVICAL CANCER AT VINA ESTETIKA HOSPITAL, MEDAN
}

\author{
Hendrika A Silitonga'), Catherine Arrigo Saachie ${ }^{2)}$ \\ 1)Department of Histology, Faculty of Medicine, Universitas Methodist Indonesia \\ 2)Faculty of Medicine, Universitas Methodist Indonesia
}

\begin{abstract}
Background: Worldwide, cervical cancer is the $4^{\text {th }}$ most common cancer among women with an estimated 528,000 new cases. Obesity and parity are known to be linked to health risks. However, the studies about obesity and parity to become a risk factor for all cancer and site-specific cancers in Indonesia are lacking. This study aimed to analyze the association of obesity and parity with the incidence of cervical cancer at Vina Estetika hospital, Medan.

Subjects and Method: This was a case control study conducted at Vina Estetica General Hospital Medan, North Sumatera, from 2017 to 2018. A total of 84 female patients was selected for this study, consisting of 42 women with cervical cancer in the case group and 42 women without cervical cancer in the control group. The dependent variable was cervical cancer. The independent variables were obesity and parity. The data were collected from medical record and analyzed using a multiple logistic regression.

Results: In the case group, 18 (42.9\%) patients were obese. In the control group, 8 (19\%) patients were obese. Obesity $(\mathrm{OR}=3.19 ; \mathrm{p}=0.018)$ and parity $\geq 4(\mathrm{OR}=3.86 ; \mathrm{p}=$ o.018) increased the risk of cervical cancer.
\end{abstract}

Conclusion: Obesity and parity increase the incidence of cervical cancer.

Keywords: obesity, parity, cervical cancer

Correspondence:

Hendrika A Silitonga. Department of Histology, Faculty of Medicine, Universitas Methodist Indonesia, Medan, North Sumatera, Indonesia. Email: andr3842@gmail.com. Mobile: 081361430688.

The $6^{\text {th }}$ International Conference on Public Health Best Western Premier Hotel, Solo, Indonesia, October 23-24, 2019 | 74 